\title{
MENINGKATKAN AKTIVITAS BELAJAR IPA SISWA KELAS V-A SDN NO. 343 KUBANGAN TOMPEK DENGAN PENERAPAN MODEL PEMBELAJARAN KERJA LAPANGAN
}

\author{
Maizarni \\ Guru IPA di SD Negeri No.343 Kubangan Tompek \\ Surel : maizarni@yahoo.co.id
}

\begin{abstract}
ABSTRAK
Penelitian ini bertujuan untuk mengetahui peningkatan aktivitas belajar menggunakan model pembelajaran kerja lapangan terhadap keberhasilan belajar pada pelajaran IPA di kelas V-A SDN No. 343 Kubangan Tompek Tahun Pelajaran 2014/2015. Subjek dalam penelitian ini adalah siswa kelas V-A dengan jumlah siswa sebanyak 26 orang yang akan diberikan tindakan berupa pengajaran melalui model pembelajaran kerja lapangan. Setelah data terkumpul dan dilakukan analisis maka diperoleh hasil analisisnya : 1) Pada siklus I pertemuan 1 dari 26 orang siswa yang menjadi subjek dalam penelitian ini, ternyata hanya hanya 5 orang siswa $(19,23 \%)$ yang sudah aktif dalam belajar, sedangkan selebihnya yaitu 21 orang siswa $(80,77 \%)$ belum aktif didalam belajar. Nilai rata - rata yang diperoleh hanya mencapai 56,09. Kemudian di pertemuan kedua, dari 26 orang siswa ternyata 11 orang siswa yang aktif di dalam belajar $(42,31)$, dan terdapat 15 orang siswa yang belum aktif dalam belajar (57,69\%). Dan nilai rata-rata pada siklus I pertemuan 2 adalah 63,22. 2) Kemudian setelah diberikan tindakan pada siklus II sebanyak dua kali pertemuan, siswa kembali diberi test aktivitas belajar pada siklus II pertemuan 3 yang kemudian diperoleh ternyata dari 26 orang siswa, diperoleh 18 orang yang sudah aktif $(69,23 \%)$ dan 8 orang yang belum aktif dalam belajar $(30,77 \%)$. Nilai rata-rata siklus II pertemuan 3 adalah 71,03. Kemudian siklus II pertemuan 4, terdapat 24 orang siswa yang aktif dalam belajar $(92,31 \%)$ dan 2 orang yang belum aktif dalam belajar (7,69\%). Nilai rata-rata siklus II pertemuan 4 adalah 87,86.
\end{abstract}

Kata kunci : Aktivitas Belajar, Kerja Lapangan, IPA

\section{PENDAHULUAN}

Pendidikan IPA seharusnya dilaksanakan dengan baik dalam proses pembelajaran di sekolah mengingat pentingnya pelajaran tersebut seperti, IPA berguna bagi kehidupan atau pekerjaan anak dikemudian hari, bagian kebudayaan bangsa dan melatih anak berpikir kritis. Pembelajaran IPA dikatakan berhasil apabila semua tujuan pembelajaran yang telah ditentukan dapat tercapai namun, dalam kenyataannya, masih ada sekolah - sekolah yang memiliki hasil belajar IPA yang rendah karena belum mencapai standar ketuntasan yang telah ditentukan.

Pembelajaran IPA di sekolah dasar selalu mengacu pada kurikulum IPA. Dalam kurikulum telah ditegaskan bahwa dalam pembelajaran IPA harus menekankan pada penguasaan kompetensi melalui serangkaian proses ilmiah. Proses 
pembelajaran IPA yang diharapkan adalah yang dapat mengembangkan keterampilan proses, pemahaman konsep, sikap ilmiah siswa, serta mendasarkan pada kegiatan IPA yang berkembang di masyarakat.

Pembelajaran IPA di sekolah dasar masih banyak dilakukan secara konvensional/tradisional (pembelajaran berpusat pada guru) serta lemahnya kemampuan guru dalam mendorong dan memotivasi siswa menjadikan prestasi belajar IPA masih rendah bila dibandingkan dengan mata pelajaran lainnya. Hal tersebut peneliti temukan pada saat melakukan observasi di kelas V-A SDN No. 343 Kubangan Tompek, dimana pelajaran IPA selalu disajikan secara verbal melalui kegiatan ceramah dan textbook oriented, dengan keterlibatan siswa yang sangat minim karena siswa hanya melakukan kegiatan duduk, diam, mendengar, mencatat dan menghafal, sehingga kurang menarik minat siswa dan membosankan yang akhirnya membuat siswa mudah lupa terhadap konsep yang telah diberikan.

Berdasarkan dari pengalaman mengajar yang sebelumnya, peneliti melihat bahwa sebenarnya pembelajaran jika dilaksanakan bervariasi apalagi dalam konsep diluar kelas dan mengenal lingkungan sekitar mereka pasti tertarik dan termotivasi. Sebelumnya peneliti juga pernah melaksanakan aktivitas serupa namun tidak sebaik metode kerja lapangan.
Kemudian sebelumnya peneliti juga melihat, bahwa selama ini pembelajaran yang disampaikan guru ke siswa hanya sebatas dengan pembelajaran yang dilakukan di dalam kelas saja, kemudian selalu menggunakan model pembelajaran yang monoton. Sehingga kreativitas siswa, motivasi siswa, dan kemampuan siswa tidak akan berkembang dengan baik.

Rendahnya pemahaman belajar siswa tersebut setelah ditelusuri antara lain disebabkan oleh beberapa faktor. Faktor dari guru, kurang bervariasi dalam penggunaan model karena minimnya peralatan, dan terlalu sering menggunakan model ceramah dan tanya jawab saja. Sedangkan faktor dari siswa, kurang melakukan eksperimen yang memadai untuk Kompetensi Dasar yang membutuhkan penalaran dan pembuktian konsep/teori karena kurang tersedianya peralatan eksperimen di sekolah. Akibatnya guru menyampaikan pembelajaran lebih banyak dengan pendekatan ekspositoris, sedangkan siswa hanya dijejali dengan konsep-konsep saja tanpa praktikum. Hal ini menjadikan siswa kesulitan menguasai materi IPA karena pembelajaran yang dilakukan belum mengakomodir secara optimal kebutuhan tersebut.

Kemampuan guru dalam merancang strategi, model, dan media mutlak dibutuhkan. Tidak 
semua model cocok untuk sebuah pembelajaran. Ada model yang cocok dengan pembelajaran tertentu, dan ada pula yang kurang sesuai. "keberhasilan implementasi strategi pembelajaran sangat tergantung pada cara guru menggunakan model pembelajaran". Pembelajaran IPA dengan menyertakan strategi, model, dan media yang tepat akan menumbuhkan rasa ketertarikan siswa akan pembelajaran IPA yang dilaksanakan. Kerja lapangan dinilai cocok dalam meningkatkan aktivitas pembelajaran IPA ini.

Metode kerja lapangan adalah suatu cara mengajar dengan cara mengajak siswa ke suatu tempat diluar yang bertujuan tidak hanya sekedar melakukan observasi atau peninjauan saja, tetapi langsung terjun/aktif berpartisipasi ke lapangan kerja, agar siswa dapat menghayati sendiri dan mengadakan penyelidikan serta bekerja sendiri di dalam pekerjaan yang ada di masyarakat.

Penerapan model pembelajaran kerja lapangan siswa akan dituntut lebih kreatif dan semakin meningkatkan kualitas pembelajaran. Selama ini siswa hanya mendapatkan pembelajaran di dalam kelas tanpa ada variasi yang dilakukan guru. Siswa hanya menerima dari apa yang mereka dengarkan. Sehubungan dengan masalah yang dihadapi oleh para siswa, maka harus segera dilakukan tindakan melalui penelitian dengan judul : "Meningkatkan Aktivitas Belajar IPA Siswa Kelas V-A SDN No. 343 Kubangan Tompek Dengan Penerapan Model Pembelajaran Kerja Lapangan T.P 2014/2015.

Sebagaimana yang telah diuraikan dalam latar belakang masalah diatas maka dapat diidentifikasi masalah dalam penelitian yaitu :

1. Strategi yang dipilih dan digunakan guru belum sesuai dengan materi yang diajarkan

2. Siswa kurang memahami konsep dengan baik kemudian kurangnya motivasi untuk mengikuti proses pembelajaran.

3. Kurang tertarik dengan materi yang disajikan guru.

4. Kemauan belajar siswa terhadap pelajaran IPA masih rendah.

5. Tidak berani mengajukan pertanyaan, kemudian tidak dapat menjawab dengan benar pertanyaan yang diajukan guru.

6. Perencanaan waktu belum diorganisasikan dengan baik sehingga waktu tidak efektif.

Mengingat keterbatasan peneliti baik dari segi kemampuan waktu dan biaya maka masalah dalam penelitianpun perlu. Adapun batasan masalah yang akan diteliti dalam penelitian ini adalah "Meningkatkan Aktivitas Belajar IPA Siswa Kelas VA SDN No. 343 Kubangan Tompek 
Dengan Penerapan Model

Pembelajaran Kerja Lapangan T.P 2014/2015".

Berdasarkan latar belakang diatas yang menjadi rumusan masalah dalam penelitian ini adalah "Apakah Dengan Menerapkan Model Pembelajaran Kerja Lapangan Dapat Meningkatkan Aktivitas Belajar IPA Siswa Kelas V-A SDN No. 343 Kubangan Tompek T.P 2014/2015".

Tujuan yang hendak dicapai dalam penelitian ini adalah "Untuk Meningkatkan Aktivitas Belajar IPA Siswa Kelas V-A SDN No. 343 Kubangan Tompek Dengan Penerapan Model Pembelajaran Kerja Lapangan T.P 2014/2015.

Penelitian ini diharapkan bermanfaat bagi pengembangan teori ilmu pendidikan. Adapun secara praktis manfaat dari hasil penelitian ini adalah:

1. Bagi sekolah, penelitian ini bermanfaat sebagai bahan untuk perbaikan dalam pembelajaran IPA.

2. Bagi guru, diharapkan dapat bermanfaat untuk memperbaiki dan melakukan penerapan model Kerja Lapangan.

3. Bagi siswa diharapkan mampu meningkatkan aktivitas belajar yang bermuara pada meningkatnya hasil belajar setelah diadakannya perlakuan dalam penelitian ini.
4. Bagi peneliti, dapat meningkatkan keterampilan peneliti dalam menerapkan penggunaan model pembelajaran Kerja Lapangan.

\section{METODE PENELITIAN}

\section{Lokasi (Tempat) dan Waktu Penelitian}

Lokasi penelitian ini

dilaksanakan di SDN No. 343 Kubangan Tompek yang beralamat di Jl. Litas Natal-Batahan Kec Batahan, Kabupaten Mandailing Natal. Penelitian ini dilaksanakan pada Agustus 2014 sampai Nopember 2014.

\section{Subjek Penelitian}

Subjek penelitian ini adalah siswa Kelas V-A SDN No. 343 Kubangan Tompek Tahun Pelajaran 2014/2015 dengan jumlah siswa sebanyak 26 orang.

\section{Metode Penelitian}

Metode penelitian ini adalah Penelitian Tindakan kelas (Classroom Action Research). Pendekatan yang digunakan adalah pendekatan kualitatif yang berguna untuk mengungkapkan kesulitan belajar siswa dalam proses pembelajaran serta cara mengatasi kesulitan-kesulitan tersebut sebagai upaya untuk meningkatkan hasil belajar siswa pada materi. Menurut Arikunto, (2010:16) menyatakan bahwa secara garis besar dalam tiap siklus itu terhadap empat tahap yang dilalui dalam melaksanakan penelitian tindakan kelas, yaitu perencanaan 
(planning), tindakan (acting), observasi (observing) dan refleksi (reflecting).

\section{Desain Penelitian}

Penelitian ini dilakukan dalam dua siklus yang di dalamnya terdapat empat tahapan utama, yaitu perencanaan, tindakan, pengamatan dan refleksi seperti yang digambarkan dibawah ini:

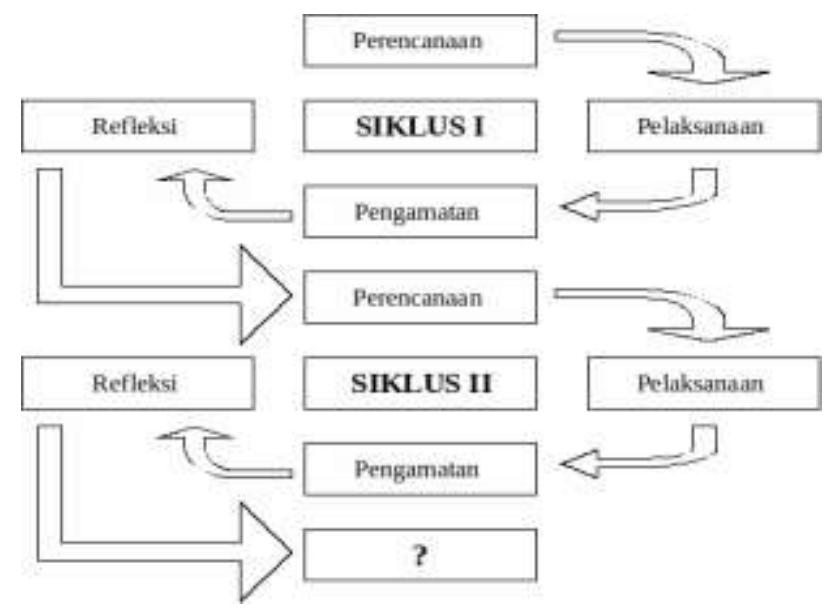

Gambar 3.1. Skema PTK Menurut Arikunto (2010:16)

\section{Siklus I}

\section{Tahap Perencanaan}

Pada tahap perencanaan ini yang dilakukan adalah merencanakan tindakan yang akan dilakukan yaitu berupa skenario pembelajaran. Kegiatan yang dilakukan dalam tahap perencanaan siklus I adalah sebagai berikut :

1) Melakukan pengamatan secara langsung keadaan sekolah, baik ruang kelas guru maupun peserta didik.
2) Mengidentifikasi masalah dan menentukan alternatif pemecahannya.

3) Membuat rencana pelaksanaan pembelajaran (RPP).

4) Mempersiapkan pembelajaran dengan menggunakan metode Kerja Lapangan.

5) Mempersiapkan media, bahan, dan alat sumber belajar.

6) Membuat lembar observasi untuk mengamati pembelajaran.

7) Menyusun alat evaluasi untuk mengetahui tingkat keberhasilan siswa.

\section{Tahap Pelaksanaan Tindakan}

Setelah tahap perencanaan disusun, maka tahap selanjutnya adalah melaksanakan rencana pembelajaran yang telah direncanakan RPP. Pelaksanaan tindakan tersebut yaitu :

1) Pada pertemuan pertama, peneliti mengajak siswa untuk belajar di luar kelas. Sesuai dengan materi pembelajaran yang dipilih "tumbuhan hijau". Peneliti merancang pembelajaran dilakukan di alam.

2) Untuk tempat yang sesuai dengan materi pembelajaran, peneliti memilih tempat "di lingkungan sekolah". Untuk sekitar lingkungan sekolah dinilai masih asri dan banyak pohon-pohon.

3) Siswa diajak ke daerah tersebut, untuk mengamati seluruh tumbuhan. Dan guru membimbing 
setiap pembelajaran di luar kelas. Guru mengarahkan pembelajaran agar siswa tidak bermain.

4) Guru memberikan sebuah masalah/ tugas kepada siswa. Siswa disuruh mencatat kegiatan mereka selama diluar. Mulai dari tumbuhan apa yang mereka lihat, bagaimanakah warna daun dari tanaman tersebut, mengambil contoh daun yang mereka lihat, dan guru menjelaskan bagaimana terjadinya fotosintesis pada daun. Kemudian guru menjelaskan akar dan mulai mencari contohnya pada tanaman kecil.

5) Setelah siswa melakukan seluruh kegiatan diluar kelas.

6) Guru menyuruh siswa masuk ke dalam kelas, dan guru membimbing siswa hingga siswa menemukan 1 permasalahan pada proses pembelajaran di luar kelas.

7) Ketika di dalam kelas, suruh siswa mengerjakan laporan kegiatan yang ia lakukan sewaktu diluar kelas.

8) Kemudian, guru membaginya beberapa kelompok untuk mendiskusikan permasalahan (materi) yang di berikan guru selanjutnya.

9) Setelah mereka berdiskusi, mereka membuat laporan kelompok dan dibagikan kepada guru.

10) Setelah itu, guru melakukan observasi pada siswa, untuk menilai peningkatan aktivitas belajar siswa selama pembelajaran berlangsung.

\section{Tahap Observasi}

Observasi dilakukan untuk mengetahui kesesuaian tindakan dengan rencana yang telah ditetapkan sekaligus mengetahui sejauh mana tindakan dapat menghasilkan perubahan yang sesuai dengan yang dikehendaki. Peneliti juga dapat melihat kesulitan-kesulitan yang dialami siswa sewaktu pembelajaran berlangsung.

\section{Tahap Refleksi}

Tahap refleksi dilakukan dengan mempertimbangkan pedoman mengajar yang dilakukan serta melihat kesesuaian yang dicapai dengan yang diinginkan dalam pembelajaran yang pada akhirnya di temukan kelebihan dan kekurangan, dimana jika ditemukan kekurangan maka akan dilakukan tindakan perbaikan pada siklus II.

Setelah siklus I dijalankan dan hasil yang dicapai belum sesuai dengan yang diharapkan, maka dilakukan kembali tahap-tahap diatas untuk dilakukan pada siklus II dan siklus selanjutnya sampai hasil belajar yang diharapkan tercapai. Pelaksanaan siklus II dilaksanakan setelah melakukan perbaikan-perbaikan pada rencana pembelajaran dan tindakan yang akan dilakukan dengan urutan- 
urutan seperti yang dilaksanakan pada siklus I.

\section{Siklus II}

\section{Tahap Perencanaan}

Tahap ini dilakukan untuk melihat sejauh mana kemampuan siswa dalam menyelesaikan soal-soal yang disajikan yang bersumber dari materi "tumbuhan hijau" dalam pelajaran sains setelah dilakukan tindakan pertama. Pada tahap ini kegiatan yang dilakukan berupa perbaikan skenario pembelajaran (RPP) yang disesuaikan refleksi tindakan pada siklus I dengan langkahlangkah sebagai berikut :

1) Mengidentifikasi masalah yang muncul pada siklus I dan mencari alternatif pemecahan masalah.

2) Mengembangkan indikator pencapaian hasil belajar.

3) Mengembangkan skenario pembelajaran.

4) Menentukan langkah-langkah yang akan dilakukan dalam kegiatan pembelajaran.

\section{Tahap Pelaksanaan Tindakan}

Kegiatan yang dilaksanakan dalam tahap ini adalah melaksanakan rencana pembelajaran yang telah direncanakan, berupa proses pembelajaran sesuai dengan rencana pembelajaran dan disesuaikan dengan hasil refleksi siklus I. Adapun skenario pembelajaran yang dilakukan adalah :

1) Pada siklus II ini, peneliti lebih membimbing siswa yang memiliki kelemahan pada siklus I sebelumnya. Kemudian meningkatkan proses-proses yang kurang pada saat siklus I berlangsung.

2) Pada pertemuan siklus II ini, peneliti mengajak siswa untuk belajar di luar kelas. Sesuai dengan materi pembelajaran yang dipilih "tumbuhan hijau". Peneliti merancang pembelajaran dilakukan di alam.

3) Untuk tempat yang sesuai dengan materi pembelajaran, peneliti memilih tempat "di lingkungan sekolah". Untuk sekitar lingkungan sekolah dinilai masih asri dan banyak pohon-pohon.

4) Siswa diajak ke daerah tersebut, untuk mengamati seluruh tumbuhan. Dan guru membimbing setiap pembelajaran di luar kelas. Guru mengarahkan pembelajaran agar siswa tidak bermain.

5) Guru memberikan sebuah masalah/ tugas kepada siswa. Siswa disuruh mencatat kegiatan mereka selama diluar. Mulai dari tumbuhan apa yang mereka lihat, bagaimanakah warna daun dari tanaman tersebut, mengambil contoh daun yang mereka lihat, dan guru menjelaskan bagaimana terjadinya fotosintesis pada daun. Kemudian guru menjelaskan akar dan mulai mencari contohnya pada tanaman kecil.

6) Setelah siswa melakukan seluruh kegiatan diluar kelas. Guru 
menyuruh siswa masuk ke dalam kelas, dan guru membimbing siswa hingga siswa menemukan 1 permasalahan pada proses pembelajaran di luar kelas.

7) Ketika di dalam kelas, suruh siswa mengerjakan laporan kegiatan yang ia lakukan sewaktu diluar kelas.

8) Kemudian, guru membaginya beberapa kelompok untuk mendiskusikan permasalahan (materi) yang di berikan guru selanjutnya.

9) Setelah mereka berdiskusi, mereka membuat laporan kelompok dan dibagikan kepada guru.

10) Setelah itu, guru melakukan tes hasil belajar pada siswa, untuk menilai peningkatan aktivitas belajar siswa selama pembelajaran berlangsung.

\section{Tahap Observasi}

Observasi yang dilaksanakan meliputi pengamatan secara langsung proses pembelajaran di kelas. Kegiatan yang diamati meliputi aktivitas guru dalam pembelajaran. Pengamatan ini bertujuan untuk mengetahui kesesuaian tindakan dengan rencana yang telah disusun dan berguna untuk mengetahui sejauh mana pelaksanaan tindakan dapat menghasilkan perubahan sesuai dengan yang dikehendaki.

\section{Tahap Refleksi}

Pada akhir siklus II siswa diberikan tes berupa individu. Kegiatan ini dilakukan melihat hasil perkembangan kemampuan siswa dalam menyelesaikan masalah yang diberikan oleh peneliti setelah diterapkannya metode Kerja Lapangan.

\section{Teknik Pengumpulan Data}

Untuk mengumpulkan data dalam penelitian ini, alat pengukur data yang digunakan adalah lembar observasi.

Pengumpulan data dengan observasi dilakukan selama proses pembelajaran berlangsung dibantu oleh guru teman sejawat. Observasi dimaksudkan untuk mengetahui bagaimana pelaksanaan tindakan dapat menghasilkan perubahan aktivitas siswa baik melibatkan seluruh domain belajar (kognitif, afektif, psikomotorik) sehingga siswa menjadi lebih aktif dalam kegiatan pembelajaran. 
Tabel Lembar Observasi Aktivitas Penilaian Siswa

Berilah tanda ceklis pada kolom yang disediakan!

\begin{tabular}{|c|c|c|c|c|}
\hline No & $\begin{array}{c}\text { Aspek Yang } \\
\text { Dinilai }\end{array}$ & Deskriptor & $\begin{array}{c}\text { Ceklis } \\
\text { Skala Penilaian } \\
(\sqrt{ })\end{array}$ & Jumlah \\
\hline 1 & $\begin{array}{c}\text { Pemahaman } \\
\text { Terhadap } \\
\text { Materi Yang } \\
\text { Disampaikan } \\
\text { Guru }\end{array}$ & $\begin{array}{l}\text { 1. Cepat menangkap materi } \\
\text { yang disampaikan oleh } \\
\text { guru. } \\
\text { 2. Timbulnya rasa ingin tahu. } \\
\text { 3. Tidak perlu dijelaskan } \\
\text { berulang-ulang. } \\
\text { 4. Adanya rasa penasaran } \\
\text { dengan kelanjutan materi. }\end{array}$ & & \\
\hline 2 & $\begin{array}{c}\text { Kemampuan } \\
\text { Melaksanakan } \\
\text { Pembelajaran } \\
\text { Dengan }\end{array}$ & $\begin{array}{l}\text { 1. Dapat menjelaskan } \\
\text { pembelajaran latihan } \\
\text { dengan baik. } \\
\text { 2. Teknik penyusunan } \\
\text { pertanyaan. } \\
\text { 3. Pengelolaan kegiatan } \\
\text { belajar. } \\
\text { 4. Memberikan penghargaan } \\
\text { individu dan kelompok. }\end{array}$ & & \\
\hline 3 & $\begin{array}{c}\text { Keaktifan } \\
\text { Dalam Proses } \\
\text { Pembelajaran }\end{array}$ & $\begin{array}{l}\text { 1. Ada respon yang baik } \\
\text { kepada guru. } \\
\text { 2. Ada umpan balik siswa } \\
\text { kepada guru. } \\
\text { 3. Antusias mengikuti proses } \\
\text { pembelajaran dalam } \\
\text { kelompok. } \\
\text { 4. Motivasi siswa yang tinggi. }\end{array}$ & & \\
\hline 4 & $\begin{array}{c}\text { Kemampuan } \\
\text { Bertanya }\end{array}$ & $\begin{array}{l}\text { 1. Berani mengajukan } \\
\text { pertanyaan tentang hal yang } \\
\text { belum dimengerti. } \\
\text { 2. Selain bertanya, siswa juga } \\
\text { mendapatkan jawaban yang } \\
\text { benar dari guru. } \\
\text { 3. Pertanyaan yang diajukan } \\
\text { tidak lari dari pembahasan. } \\
\text { 4. Tidak cepat merasa puas } \\
\text { dengan materi yang belum } \\
\text { dimengerti. }\end{array}$ & & \\
\hline
\end{tabular}




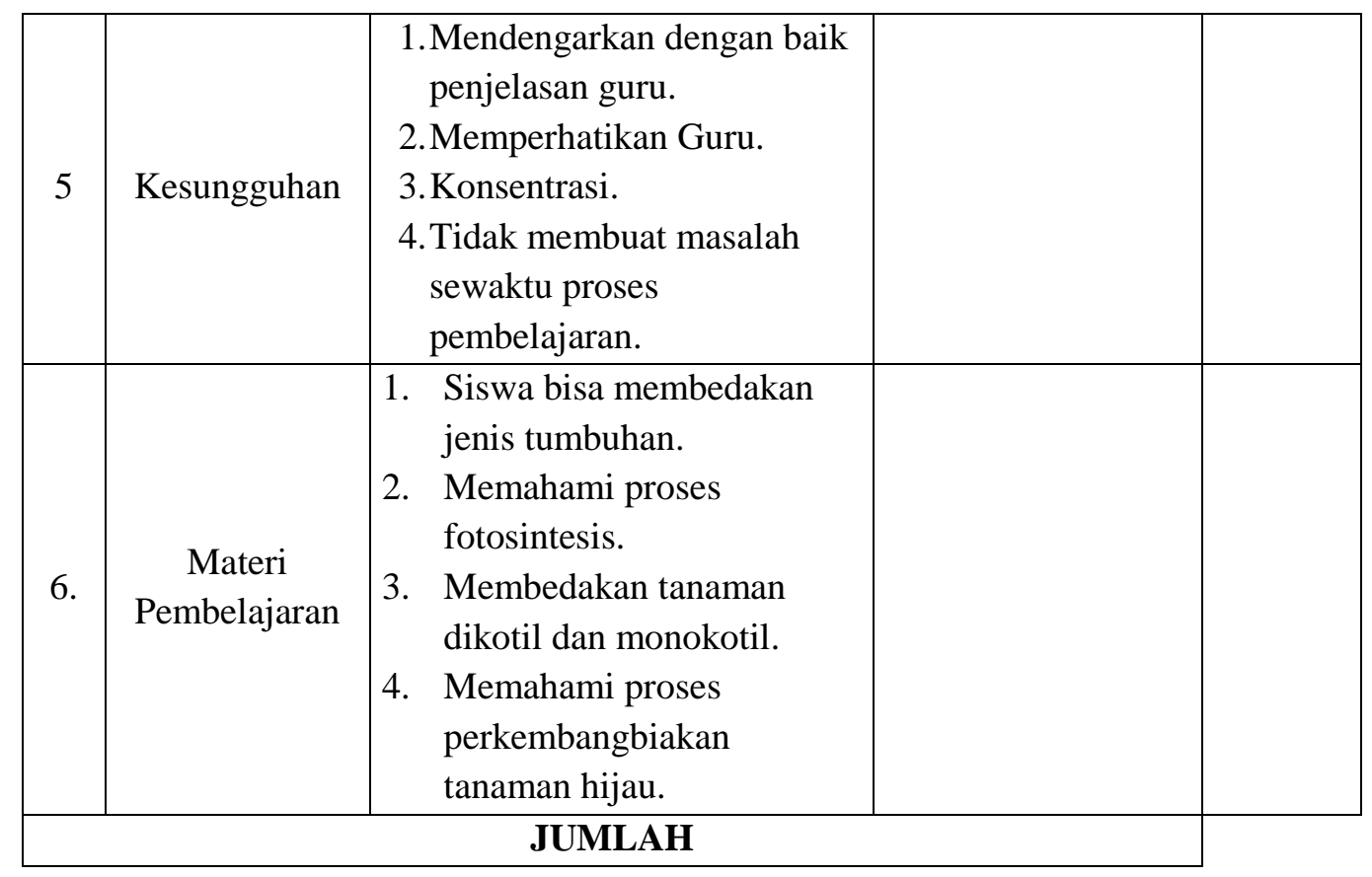

Keterangan :

1. Sangat Baik : Jika melakukan 4 deskriptor.

2. Baik : Jika melakukan 3 deskriptor.

3. Kurang Baik : Jika melakukan 2 deskriptor.

4. Tidak Baik : Jika melakukan 1 deskriptor.

\section{Teknik Analisis Data}

Data aktivitas belajar siswa diperoleh dari lembar observasi yang terlihat dari aktivitas belajar siswa selama proses pembelajaran dikelas. Data yang diperoleh dianalisis secara deskriptif berdasarkan tahap keberhasilan tindakan yaitu dari frekuensi kemunculan indikator pada lembar observasi.
Adapun yang menjadi analisis data aktivitas siswa adalah sebagai berikut:

a. Ketercapaian Aktivitas Siswa Secara Individu

Ketercapaian aktivitas siswa secara individu dapat diketahui dengan menghitung persentase keberhasilan yang diperoleh setiap individu dari hasil observasi dengan menggunakan rumus sebagai berikut :

$$
\mathrm{PH}=\frac{\mathrm{B}}{\mathrm{N}} \times 100
$$

Dimana $: \mathrm{PH}=$ persentase aktivitas belajar

$\mathrm{B}=$ skor yang di peroleh siswa

$\mathrm{N}=$ skor maksimum 
Sedangkan skor keaktifan yang di nilai adalah sebagai berikut :

$0-100$ dikatakan aktif

$0-64$ dikatakan tidak aktif

(Purwoko, 2006:103)

b. Ketercapaian Aktivitas Siswa Secara Klasikal

Ketercapaian aktivitas siswa secara klasikal dapat diketahui dengan menghitung persentase keberhasilan klasikal siswa dengan menggunakan rumus sebagai berikut :

$$
\mathrm{P}=\frac{f}{n} \times 100 \%
$$

(Sudjana, 2009)

Dimana : $\mathrm{P}=$ nilai persentase yang diperoleh

$\mathrm{f}=$ jumlah siswa yang mengalami perubahan

$\mathrm{n}=$ jumlah banyaknya individu

\section{HASIL DAN PEMBAHASAN PENELITIAN \\ Deskripsi Data Penelitian}

Penelitian ini dilaksanakan di SDN No. 343 Kubangan Tompek Tahun Ajaran 2014/2015. Penelitian ini dilakukan dalam dua siklus, dimana setiap siklus berisikan tindakan berupa pelaksanaan pembelajaran dengan model pembelajaran kerja lapangan yang disesuaikan dengan materi pelajaran.

\section{Pelaksanaan Siklus I Permasalahan}

Berdasarkan hasil pengamatan peneliti sebagai guru kelas V SDN No. 343 Kubangan Tompek permasalahan yang dialami siswa dalam mempelajari materi tentang Tumbuhan hijau pada pelajaran pendidikan Ilmu Pengetahuan Alam adalah siswa kurang dapat memahami bagaimana Tumbuhan hijau itu, sehingga untuk pembelajaran pada materi ini hasilnya sangat rendah.

\section{Perencanaan}

Rencana tindakan untuk mengatasi permasalahan yang dialami siswa dalam penguasaan materi Tumbuhan hijau pelajaran Ilmu Pengetahuan Alam. Pemecahan masalah yang dilakukan adalah dengan melaksanakan pembelajaran sesuai dengan yang sudah direncanakan dalam RPP.

Adapun langkah-langkah yang ditempuh pada rencana tindakan I adalah :

1. Mempersiapkan dan menyusun nama-nama siswa.

2. Mempersiapkan rencana pelaksanaan pembelajaran yang telah dibuat, sebagai upaya untuk menyelesaikan permasalahan I.

3. Mempersiapkan model pembelajaran kerja lapangan yang akan digunakan dalam materi Tumbuhan hijau pada pelajaran Ilmu Pengetahuan Alam. 
4. Mempersiakan lapangan (tempat) yang akan dijadikan sebagai objek pembelajaran siswa.

5. Mensurvei tempat diluar kelas yang sesuai dengan kebutuhan belajar siswa.

6. Melaksanakan pembelajaran dengan memanfaatkan model pembelajaran kerja lapangan.

7. Selalu memberikan umpan balik yang mampu memotivasi siswa untuk melakukan kegiatan yang lebih baik lagi.

8. Melaksanakan diskusi kelompok di kelas.

9. Memberikan kesempatan kepada siswa untuk bertanya dan berdiskusi mengupayakan agar setiap siswa aktif dan menanyakan kesulitan dalam melakukan materi.

10. Mempersiapkan tes aktivitas belajar berupa lembar observasi yang diisi oleh guru.

\section{Pelaksanaan Pembelajaran pertemuan 1}

Pembelajaran difokuskan pada proses belajar yang dapat meningkatkan aktivitas belajar siswa dengan menggunakan model pembelajaran kerja lapangan dalam materi Ilmu Pengetahuan Alam pada pelajaran Ilmu Pengetahuan Alam.

1) Pada pertemuan pertama, peneliti mengajak siswa untuk belajar di luar kelas. Sesuai dengan materi pembelajaran yang dipilih "tumbuhan hijau". Peneliti merancang pembelajaran dilakukan di alam.

2) Untuk tempat yang sesuai dengan materi pembelajaran, peneliti memilih tempat "di lingkungan sekolah". Untuk sekitar lingkungan sekolah dinilai masih asri dan banyak pohon-pohon.

3) Siswa diajak ke daerah tersebut, untuk mengamati seluruh tumbuhan. Dan guru membimbing setiap pembelajaran di luar kelas. Guru mengarahkan pembelajaran agar siswa tidak bermain.

4) Guru memberikan sebuah masalah/ tugas kepada siswa. Siswa disuruh mencatat kegiatan mereka selama diluar. Mulai dari tumbuhan apa yang mereka lihat, bagaimanakah warna daun dari tanaman tersebut, mengambil contoh daun yang mereka lihat, dan guru menjelaskan bagaimana terjadinya fotosintesis pada daun. Kemudian guru menjelaskan akar dan mulai mencari contohnya pada tanaman kecil.

5) Setelah siswa melakukan seluruh kegiatan diluar kelas.

6) Guru menyuruh siswa masuk ke dalam kelas, dan guru membimbing siswa hingga siswa menemukan 1 permasalahan 
pada proses pembelajaran di luar kelas.

7) Ketika di dalam kelas, suruh siswa mengerjakan laporan kegiatan yang ia lakukan sewaktu diluar kelas.

8) Kemudian, guru membaginya beberapa kelompok untuk mendiskusikan permasalahan (materi) yang di berikan guru selanjutnya.

9) Setelah mereka berdiskusi, mereka membuat laporan kelompok dan dibagikan kepada guru.

10) Setelah itu, guru melakukan observasi pada siswa, untuk menilai peningkatan aktivitas belajar siswa selama pembelajaran berlangsung.

\section{Observasi/analisis Data Pertemuan 1}

Observasi atau pengamatan dilakukan oleh guru mulai dari awal pelaksanaan tindakan sampai akhir pelaksanaan tindakan pembelajaran yang menerapkan model pembelajaran kerja lapangan sebagai upaya meningkatkan aktivitas belajar siswa pada materi Tumbuhan hijau pada pelajaran pendidikan Ilmu Pengetahuan Alam.

Setelah proses observasi dilakukan, selanjutnya dilakukan proses analisis dari data aktivitas belajar yang didapatkan. Data aktivitas belajar siklus I pertemuan 1 yang didapat kemudian direduksi dan dipaparkan dalam bentuk tabel sebagai berikut :

Tabel Aktivitas Belajar Siswa Pada Siklus I Pertemuan 1

\begin{tabular}{|c|c|c|c|}
\hline \multirow{2}{*}{$\begin{array}{c}\text { No } \\
\text { Responden }\end{array}$} & \multicolumn{3}{|c|}{ Skor } \\
\hline & $\mathrm{Jlh}$ & $\%$ & Kriteria \\
\hline 1 & 55 & 57.29 & Tidak Aktif \\
\hline 2 & 52 & 54.17 & Tidak Aktif \\
\hline 3 & 51 & 53.13 & Tidak Aktif \\
\hline 4 & 54 & 56.25 & Tidak Aktif \\
\hline 5 & 51 & 53.13 & Tidak Aktif \\
\hline 6 & 45 & 46.88 & Tidak Aktif \\
\hline 7 & 64 & 66.67 & Aktif \\
\hline 8 & 72 & 75.00 & Aktif \\
\hline 9 & 61 & 63.54 & Tidak Aktif \\
\hline 10 & 59 & 61.46 & Tidak Aktif \\
\hline 11 & 64 & 66.67 & Aktif \\
\hline 12 & 52 & 54.17 & Tidak Aktif \\
\hline 13 & 53 & 55.21 & Tidak Aktif \\
\hline 14 & 54 & 56.25 & Tidak Aktif \\
\hline 15 & 51 & 53.13 & Tidak Aktif \\
\hline 16 & 62 & 64.58 & Tidak Aktif \\
\hline 17 & 54 & 56.25 & Tidak Aktif \\
\hline 18 & 64 & 66.67 & Aktif \\
\hline 19 & 72 & 75.00 & Aktif \\
\hline 20 & 52 & 54.17 & Tidak Aktif \\
\hline 21 & 50 & 52.08 & Tidak Aktif \\
\hline 22 & 50 & 52.08 & Tidak Aktif \\
\hline 23 & 48 & 50.00 & Tidak Aktif \\
\hline 24 & 59 & 61.46 & Tidak Aktif \\
\hline 25 & 52 & 54.17 & Tidak Aktif \\
\hline 26 & 48 & 50.00 & Tidak Aktif \\
\hline Jlh & & & \\
\hline
\end{tabular}

Dari data yang didapat terlihat bahwa kemampuan awal siswa dalam mengikuti pembelajaran materi Tumbuhan hijau pada pelajaran Ilmu 
Pengetahuan Alam masih rendah, belum seperti yang diharapkan. Dari 26 orang siswa yang menjadi subjek dalam penelitian ini, diketahui pada siklus I pertemuan 1 menunjukan bahwa hanya 5 orang siswa yang sudah aktif dalam belajar $(19,23 \%)$, dan sisanya 21 orang siswa belum aktif dalam belajar $(80,77 \%)$

Tabel Deskripsi Aktivitas Belajar Siklus I Pertemuan 1

\begin{tabular}{|c|c|c|c|c|}
\hline No & Hasil Tes & $\begin{array}{c}\text { Jumlah } \\
\text { Siswa }\end{array}$ & $\begin{array}{c}\text { Persentase } \\
(\%)\end{array}$ & Keterangan \\
\hline 1 & $\begin{array}{c}\text { Skor } \leq \\
65\end{array}$ & 21 & 80.77 & $\begin{array}{c}\text { Tidak } \\
\text { Aktif }\end{array}$ \\
\hline 2 & $\begin{array}{c}\text { Skor }> \\
65\end{array}$ & 5 & 19.23 & Aktif \\
\hline
\end{tabular}

Data deskripsi aktivitas belajar siswa siklus I pertemuan 1 tabel diatas dapat juga dilihat seperti pada gambar histogram berikut.

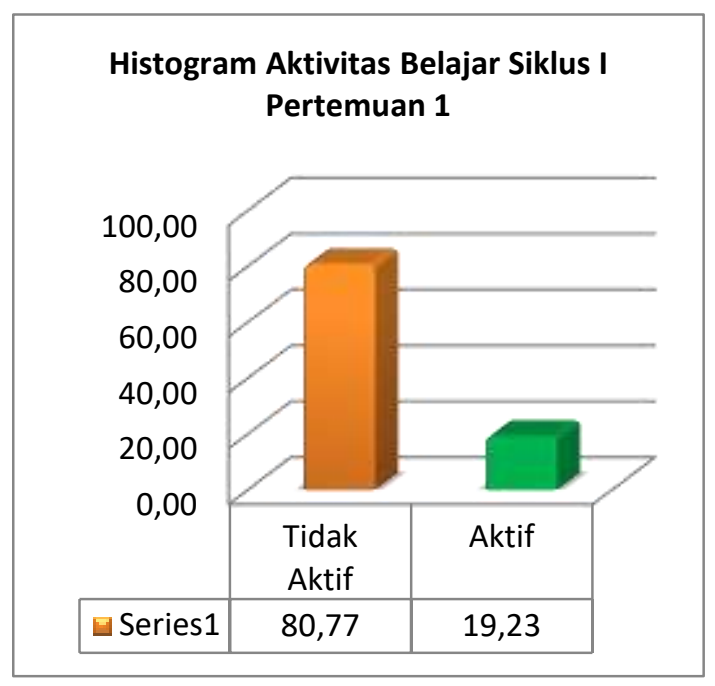

Gambar Histogram Aktivitas Belajar Siklus I Pertemuan 1

\section{Refleksi Pertemuan 1}

Dari hasil analisa data siklus I pertemuan 1 dapat disimpulkan bahwa aktivitas belajar siswa dari tes pada siklus I pertemuan 1 masih rendah. Pada siklus ini guru menemukan beberapa kesulitan. Untuk itu perlu perbaikan tindakan pada rencana pembelajaran pertemuan berikutnya..

Adapun kesulitan-kesulitan yang dialami siswa antara lain adalah:

1. Masih banyak siswa yang masih belum paham mengenai Ilmu Pengetahuan Alam pada materi Tumbuhan hijau.

2. Pada saat melaksanaan pembelajaran di lapangan, cenderung siswa tidak serius dan mengalihkan tugas yang diberikan dengan bermain bersama temannya.

3. Dalam pelaksanaan diskusi, masih banyak siswa yang bercerita dengan teman bukan berdiskusi.

4. Dalam menemukan masalah, siswa juga masih butuh bimbingan guru.

5. Motivasi siswa cukup rendah pada siklus I ini.

6. Siswa kurang mengulang pembelajarannya di rumah.

Pelaksanaan

Pembelajaran

\section{Pertemuan 2}

Pembelajaran difokuskan pada proses belajar yang dapat meningkatkan aktivitas belajar siswa dengan menggunakan model 
pembelajaran kerja lapangan dalam materi Ilmu Pengetahuan Alam pada pelajaran Ilmu Pengetahuan Alam dan difokuskan untuk memperbaiki siswa yang kurang mendengarkan penjelasan guru, siswa yang kurang membaca buku, siswa yang kurang mencatat halhal penting dari buku sehingga ketika dilapangan siswa sedikit kesulitan.

1. Pada pertemuan kedua, peneliti mengajak siswa untuk belajar di luar kelas. Sesuai dengan materi pembelajaran yang dipilih "tumbuhan hijau". Peneliti merancang pembelajaran dilakukan di alam.

2. Untuk tempat yang sesuai dengan materi pembelajaran, peneliti memilih tempat "di lingkungan sekolah". Untuk sekitar lingkungan sekolah dinilai masih asri dan banyak pohon-pohon.

3. Untuk pertemuan 1 peneliti sudah mendapatkan siswa yang kurang mau mencatat hal-hal penting dari buku dan ketika dilapangan sehingga pada pertemuan kedua, untuk beberapa siswa perlu diperhatikan khusus agar tidak terulang lagi dipertemuan 2 .

4. Siswa diajak ke daerah tersebut, untuk mengamati seluruh tumbuhan. Dan guru membimbing setiap pembelajaran di luar kelas. Guru mengarahkan pembelajaran agar siswa tidak bermain.
5. Untuk siswa yang bermain, akan diberikan hukuman jika tidak selesai melakukan tugas di luar kelas.

6. Guru memberikan sebuah masalah/ tugas kepada siswa. Siswa disuruh mencatat kegiatan mereka selama diluar. Mulai dari tumbuhan apa yang mereka lihat, bagaimanakah warna daun dari tanaman tersebut, mengambil contoh daun yang mereka lihat, dan guru menjelaskan bagaimana terjadinya fotosintesis pada daun. Kemudian guru menjelaskan akar dan mulai mencari contohnya pada tanaman kecil.

7. Setelah siswa melakukan seluruh kegiatan diluar kelas.

8. Guru menyuruh siswa masuk ke dalam kelas, dan guru membimbing siswa hingga siswa menemukan 1 permasalahan pada proses pembelajaran di luar kelas.

9. Ketika di dalam kelas, suruh siswa mengerjakan laporan kegiatan yang ia lakukan sewaktu diluar kelas.

10. Kemudian ketika di dalam kelas, guru lebih mengontrol kegiatan belajar terutama siswa harus rajin membaca buku pelajaran demi menyelesaikan tugas.

11. Kemudian, guru membaginya beberapa kelompok untuk mendiskusikan permasalahan (materi) yang di berikan guru selanjutnya.

12. Setelah mereka berdiskusi, mereka membuat laporan 
kelompok dan dibagikan kepada guru.

13. Setelah itu, guru melakukan observasi pada siswa, untuk menilai peningkatan aktivitas belajar siswa selama pembelajaran berlangsung.

\section{Observasi/analisis Data Pertemuan 2}

Observasi atau pengamatan dilakukan oleh guru mulai dari awal pelaksanaan tindakan sampai akhir pelaksanaan tindakan pembelajaran yang menerapkan model pembelajaran kerja lapangan sebagai upaya meningkatkan aktivitas belajar siswa pada materi Tumbuhan hijau pada pelajaran pendidikan Ilmu Pengetahuan Alam. Dari hasil observasi ini dapat dilihat bahwa kegiatan pembelajaran telah berlangsung dengan baik dibandingkan pada pertemuan 1 sebelumnya.

Setelah proses observasi dilakukan, selanjutnya dilakukan proses analisis dari data aktivitas belajar yang didapatkan. Data aktivitas belajar siklus I yang didapat kemudian direduksi dan dipaparkan dalam bentuk tabel sebagai berikut :

Tabel Aktivitas Belajar Siswa Pada Siklus I Pertemuan 2

\begin{tabular}{|c|c|c|c|}
\hline \multirow{2}{*}{$\begin{array}{c}\text { No } \\
\text { Responden }\end{array}$} & \multicolumn{3}{|c|}{ Skor } \\
\cline { 2 - 4 } & Jlh & $\%$ & Kriteria \\
\hline 1 & 61 & 63.54 & Tidak Aktif \\
\hline 2 & 70 & 72.92 & Aktif \\
\hline 3 & 64 & 66.67 & Aktif \\
\hline
\end{tabular}

\begin{tabular}{|c|c|c|c|}
4 & 63 & 65.63 & Aktif \\
\hline 5 & 76 & 79.17 & Aktif \\
\hline 6 & 45 & 46.88 & Tidak Aktif \\
\hline 7 & 70 & 72.92 & Aktif \\
\hline 8 & 55 & 57.29 & Tidak Aktif \\
\hline 9 & 67 & 69.79 & Aktif \\
\hline 10 & 60 & 62.50 & Tidak Aktif \\
\hline 11 & 67 & 69.79 & Aktif \\
\hline 12 & 56 & 58.33 & Tidak Aktif \\
\hline 13 & 54 & 56.25 & Tidak Aktif \\
\hline 14 & 50 & 52.08 & Tidak Aktif \\
\hline 15 & 60 & 62.50 & Tidak Aktif \\
\hline 16 & 62 & 64.58 & Tidak Aktif \\
\hline 17 & 64 & 66.67 & Aktif \\
\hline 18 & 72 & 75.00 & Aktif \\
\hline 19 & 64 & 66.67 & Aktif \\
\hline 20 & 76 & 79.17 & Aktif \\
\hline 21 & 50 & 52.08 & Tidak Aktif \\
\hline 22 & 51 & 53.13 & Tidak Aktif \\
\hline 23 & 50 & 52.08 & Tidak Aktif \\
\hline 24 & 60 & 62.50 & Tidak Aktif \\
\hline 25 & 62 & 64.58 & Tidak Aktif \\
\hline 26 & 51 & 53.13 & Tidak Aktif \\
\hline Jlh & & & \\
\hline & & & \\
\hline
\end{tabular}

Dari data yang didapat terlihat bahwa aktivitas belajar siswa pada pertemuan 2 siklus I materi Tumbuhan hijau pada pelajaran Ilmu Pengetahuan Alam masih rendah, belum seperti yang diharapkan. Dari 26 orang siswa yang menjadi subjek dalam penelitian ini, ternyata pada siklus I pertemuan 2 menunjukan bahwa hanya 11 orang siswa yang sudah aktif dalam belajar $(42,31 \% \%)$, dan sisanya 15 orang siswa tidak aktif dalam belajar $(57,69 \%)$. 
Tabel Deskripsi Aktivitas Belajar Siklus I Pertemuan 2

\begin{tabular}{|c|c|c|c|c|}
\hline No & Hasil Tes & $\begin{array}{c}\text { Jumlah } \\
\text { Siswa }\end{array}$ & $\begin{array}{c}\text { Persentase } \\
(\%)\end{array}$ & Keterangan \\
\hline 1 & Skor $\leq 65$ & 15 & 57.69 & $\begin{array}{c}\text { Tidak } \\
\text { Aktif }\end{array}$ \\
\hline 2 & Skor $>65$ & 11 & 42.31 & Aktif \\
\hline
\end{tabular}

Data deskripsi aktivitas belajar siswa siklus I pertemuan 2 tabel diatas dapat juga dilihat seperti pada gambar histogram berikut.

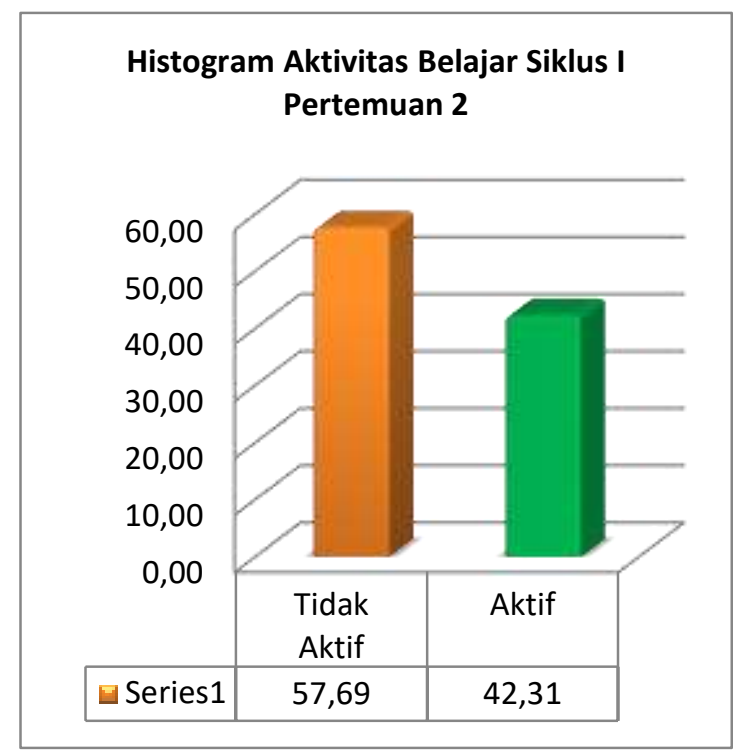

Gambar Histogram Aktivitas Belajar Siklus I Pertemuan 2

\section{Refleksi Pembelajaran Siklus I Pertemuan 2}

Dari hasil analisa data siklus I pertemuan 2 dapat disimpulkan bahwa aktivitas belajar siswa dari tes pada siklus I pertemuan 2 masih rendah. Pada siklus ini guru menemukan beberapa kesulitan. Untuk itu perlu perbaikan tindakan untuk siklus II.

Adapun kesulitan-kesulitan yang dialami siswa antara lain adalah:
1. Masih banyak siswa yang tidak mendengarkan penjelasan guru ketika di lapangan ataupun di dalam kelas.

2. Sedikit siswa yang mau membaca buku dirumah dan di sekolah.

3. Banyaknya siswa yang bermain bersama teman ketika pembelajaran di lapangan.

4. Dalam pelaksanaan diskusi, masih banyak siswa yang bercerita dengan teman bukan berdiskusi.

5. Motivasi siswa cukup rendah pada siklus I ini.

6. Siswa kurang mengulang pembelajarannya di rumah.

7. Guru juga harus lebih mengontrol jalannya pembelajaran di ruangan atau di lapangan.

\section{Pelaksanaan Siklus II Permasalahan}

Berdasarkan hasil pengamatan oleh guru kelas dan melihat kepada hasil dari siklus I maka permasalahan utama yang ditemui adalah:

1. Masih banyak siswa yang masih belum paham mengenai Ilmu Pengetahuan Alam pada materi Tumbuhan hijau.

2. Pada saat melaksanaan pembelajaran di lapangan, cenderung siswa tidak serius dan mengalihkan tugas yang diberikan dengan bermain bersama temannya. 
3. Dalam pelaksanaan diskusi, masih banyak siswa yang bercerita dengan teman bukan berdiskusi.

\section{Alternatif Pemecahan masalah}

Berdasarkan hasil refleksi peneliti, maka rencana tindakan II pertemuan 3 akan disusun untuk mengatasi masalah yang ditemukan pada siklus I dan mengatasi permasalahan yang dialami siswa selama pembelajaran Tumbuhan hijau pada pelajaran Ilmu Pengetahuan Alam. Pemecahan masalah yang dilakukan adalah dengan melaksanakan pembelajaran sesuai dengan yang sudah direncanakan dalam RPP.

Adapun langkah-langkah yang ditempuh pada rencana tindakan II adalah:

1. Mempersiapkan dan menyusun nama-nama siswa.

2. Mempersiapkan rencana pelaksanaan pembelajaran yang telah dibuat, sebagai upaya untuk menyelesaikan permasalahan I.

3. Mempersiapkan model pembelajaran kerja lapangan yang akan digunakan dalam materi Tumbuhan hijau pada pelajaran Ilmu Pengetahuan Alam ini.

4. Mempersiakan lapangan (tempat) yang akan dijadikan sebagai objek pembelajaran siswa.

5. Mensurvei tempat diluar kelas yang sesuai dengan kebutuhan belajar siswa.
6. Melaksanakan pembelajaran dengan memanfaatkan model pembelajaran kerja lapangan.

7. Selalu memberikan umpan balik yang mampu memotivasi siswa untuk melakukan kegiatan yang lebih baik lagi.

8. Melakukan pengamatan secara langsung keadaan sekolah, baik ruang kelas guru maupun peserta didik.

9. Mengidentifikasi masalah dan menentukan alternatif pemecahannya.

10. Membuat rencana pelaksanaan pembelajaran (RPP).

11. Mempersiapkan pembelajaran dengan menggunakan metode Kerja Lapangan.

12. Mempersiapkan media, bahan, dan alat sumber belajar.

13. Membuat lembar observasi untuk mengamati pembelajaran.

14. Menyusun alat evaluasi untuk mengetahui tingkat keberhasilan siswa.

15. Dalam pelaksanaan siklus II ini, lebih meminimalkan kesalahan dan kegagalan terutama dilapangan, berdasarkan permasalahan yang terjadi pada siklus I.

16. Pada materi pembelajaran yang tidak dimengerti, guru berusaha menjelaskan dan memantapkan materi. 
Pelaksanaan Pembelajaran Siklus II Pertemuan 3

Pemberian tindakan II

dilakukan berdasarkan hasil refleksi

dasi siklus I. Pada pertemuan siklus II ini siswa diarahkan untuk lebih memahami rangkaian pelaksanaan sistem Tumbuhan hijau pada pelajaran Ilmu Pengetahuan Alam. Adapun kegiatan-kegiatan yang dilakukan adalah:

1) Pada pertemuan pertama, peneliti mengajak siswa untuk belajar di luar kelas. Sesuai dengan materi pembelajaran yang dipilih "tumbuhan hijau". Peneliti merancang pembelajaran dilakukan di alam.

2) Untuk tempat yang sesuai dengan materi pembelajaran, peneliti memilih tempat "di lingkungan sekolah". Untuk sekitar lingkungan sekolah dinilai masih asri dan banyak pohon-pohon.

3) Siswa diajak ke daerah tersebut, untuk mengamati seluruh tumbuhan. Dan guru membimbing setiap pembelajaran di luar kelas. Guru mengarahkan pembelajaran agar siswa tidak bermain.

4) Guru memberikan sebuah masalah/ tugas kepada siswa. Siswa disuruh mencatat kegiatan mereka selama diluar. Mulai dari tumbuhan apa yang mereka lihat, bagaimanakah warna daun dari tanaman tersebut, mengambil contoh daun yang mereka lihat, dan guru menjelaskan bagaimana terjadinya fotosintesis pada daun. Kemudian guru menjelaskan akar dan mulai mencari contohnya pada tanaman kecil.

5) Setelah siswa melakukan seluruh kegiatan diluar kelas.

6) Guru menyuruh siswa masuk ke dalam kelas, dan guru membimbing siswa hingga siswa menemukan 1 permasalahan pada proses pembelajaran di luar kelas.

7) Ketika di dalam kelas, suruh siswa mengerjakan laporan kegiatan yang ia lakukan sewaktu diluar kelas.

8) Kemudian, guru membaginya beberapa kelompok untuk mendiskusikan permasalahan (materi) yang di berikan guru selanjutnya.

9) Setelah mereka berdiskusi, mereka membuat laporan kelompok dan dibagikan kepada guru.

10) Setelah itu, guru melakukan observasi pada siswa, untuk menilai peningkatan aktivitas belajar siswa selama pembelajaran berlangsung.

11) Pada pelaksanaan tindakan siklus II, lebih memantapkan materi dan meminimalkan siswa agar tidak ada waktu untuk bermain bersama temannya.

\section{Observasi/analisis data Pertemuan 3}

Sama halnya pada siklus I, observasi atau pengamatan II ini dilakukan oleh teman sejawat di SDN No. 343 Kubangan Tompek mulai dari 
awal pelaksanaan tindakan sampai akhir pelaksanaan tindakan pembelajaran yang menerapkan model pembelajaran kerja lapangan sebagai upaya meningkatkan aktivitas belajar siswa pada materi Tumbuhan hijau pada pelajaran Ilmu Pengetahuan Alam. Dari hasil observasi ini dapat dilihat bahwa kegiatan pembelajaran pada siklus II ini telah berlangsung dengan baik.

Setelah proses observasi II dilakukan, selanjutnya dilakukan kembali analisis dari data aktivitas belajar II yang ditetapkan. Dari aktivitas belajar siklus II yang didapat kemudian kembali reduksi dan dipaparkan bentuk tabel dengan menggunakan rumus yang sama seperti siklus I. Ternyata 18 orang siswa $(69,23 \%)$ telah aktif belajar dan sisanya 8 orang siswa tidak aktif dalam belajar $(30,77 \%)$.

Tabel Aktivitas Belajar Siswa Pada Siklus II Pertemuan 3

\begin{tabular}{|c|c|c|c|}
\hline \multirow{2}{*}{$\begin{array}{c}\text { No } \\
\text { Responden }\end{array}$} & \multicolumn{3}{|c|}{ Skor } \\
\cline { 2 - 4 } & Jlh & $\%$ & Kriteria \\
\hline 1 & 66 & 68.75 & Aktif \\
\hline 2 & 70 & 72.92 & Aktif \\
\hline 3 & 70 & 72.92 & Aktif \\
\hline 4 & 63 & 65.63 & Aktif \\
\hline 5 & 78 & 81.25 & Aktif \\
\hline 6 & 55 & 57.29 & $\begin{array}{l}\text { Tidak } \\
\text { Aktif }\end{array}$ \\
\hline 7 & 71 & 73.96 & Aktif \\
\hline 8 & 58 & 60.42 & $\begin{array}{l}\text { Tidak } \\
\text { Aktif }\end{array}$ \\
\hline 9 & 65 & 67.71 & Aktif \\
\hline
\end{tabular}

\begin{tabular}{|c|c|c|c|}
\hline 10 & 64 & 66.67 & Aktif \\
\hline 11 & 67 & 69.79 & Aktif \\
\hline 12 & 56 & 58.33 & Tidak \\
\hline 13 & 61 & 63.54 & Tidak \\
\hline 14 & 50 & 52.08 & $\begin{array}{l}\text { Tidak } \\
\text { Aktif }\end{array}$ \\
\hline 15 & 64 & 66.67 & Aktif \\
\hline 16 & 64 & 66.67 & Aktif \\
\hline 17 & 65 & 67.71 & Aktif \\
\hline 18 & 64 & 66.67 & Aktif \\
\hline 19 & 67 & 69.79 & Aktif \\
\hline 20 & 66 & 68.75 & Aktif \\
\hline 21 & 58 & 60.42 & $\begin{array}{l}\text { Tidak } \\
\text { Aktif }\end{array}$ \\
\hline 22 & 65 & 67.71 & Aktif \\
\hline 23 & 50 & 52.08 & $\begin{array}{l}\text { Tidak } \\
\text { Aktif }\end{array}$ \\
\hline 24 & 59 & 61.46 & $\begin{array}{l}\text { Tidak } \\
\text { Aktif }\end{array}$ \\
\hline 25 & 70 & 72.92 & Aktif \\
\hline 26 & 63 & 65.63 & Aktif \\
\hline Jlh & & & \\
\hline
\end{tabular}

Dari data yang didapat terlihat bahwa aktivitas belajar siswa pada pertemuan 3 siklus II materi Tumbuhan hijau pada pelajaran Ilmu Pengetahuan Alam terus mengalami perbaikan. Dari 26 orang siswa yang menjadi subjek dalam penelitian ini, ternyata pada siklus II pertemuan 3 menunjukan bahwa 18 orang siswa yang sudah aktif dalam belajar $(69,23 \%)$, dan sisanya 8 orang siswa tidak aktif dalam belajar $(30,77 \%)$. 
Tabel Deskripsi Aktivitas Belajar

Siklus II Pertemuan 3

\begin{tabular}{|c|l|c|c|c|}
\hline No & Hasil Tes & $\begin{array}{c}\text { Jumlah } \\
\text { Siswa }\end{array}$ & $\begin{array}{c}\text { Persentase } \\
(\%)\end{array}$ & Keterangan \\
\hline 1 & Skor $\leq 65$ & 8 & 30.77 & $\begin{array}{c}\text { Tidak } \\
\text { Aktif }\end{array}$ \\
\hline 2 & Skor $>65$ & 18 & 69.23 & Aktif \\
\hline
\end{tabular}

Data deskripsi aktivitas belajar siswa siklus II pertemuan 3 tabel diatas dapat juga dilihat seperti pada gambar histogram berikut.

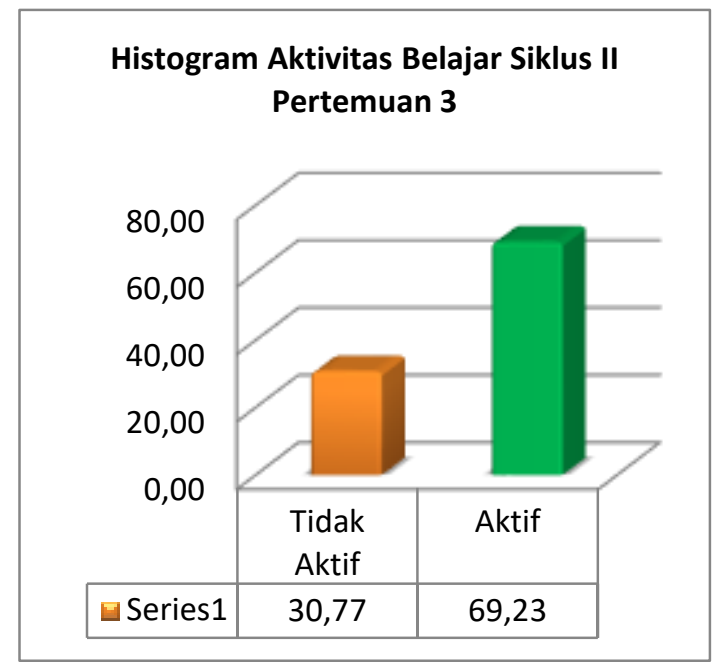

Gambar Histogram Aktivitas Belajar Siklus II Pertemuan 3

\section{Pelaksanaan Pembelajaran Siklus II Pertemuan 4}

Pemberian tindakan pertemun 4 dilakukan berdasarkan hasil refleksi dari pertemuan sebelumnya. Pada pertemuan 4 siklus II ini siswa diarahkan untuk lebih memahami rangkaian pelaksanaan sistem Tumbuhan hijau pada pelajaran Ilmu Pengetahuan Alam. Adapun kegiatankegiatan yang dilakukan adalah:

1. Pada pertemuan kedua siklus II, peneliti mengajak siswa untuk belajar di luar kelas. Sesuai dengan materi pembelajaran yang dipilih "tumbuhan hijau". Peneliti merancang pembelajaran dilakukan di alam.

2. Ketika di lapangan, peneliti tetap memantau jalannya pembelajarannya.

3. Membimbing siswa dalam membedakan jenis tumbuhan.

4. Menjelaskan proses fotosintesis pada tumbuhan.

5. Siswa mencatat hal-hal yang disuruh guru untuk di catat atau didokumentasikan.

6. Guru menyuruh siswa masuk ke dalam kelas, dan guru membimbing siswa hingga siswa menemukan 1 permasalahan pada proses pembelajaran di luar kelas.

7. Ketika di dalam kelas, suruh siswa mengerjakan laporan kegiatan yang ia lakukan sewaktu diluar kelas.

8. Kemudian, guru membaginya beberapa kelompok untuk mendiskusikan permasalahan (materi) yang di berikan guru selanjutnya.

9. Setelah mereka berdiskusi, mereka membuat laporan kelompok dan dibagikan kepada guru.

10. Setelah itu, guru melakukan observasi pada siswa, untuk menilai peningkatan aktivitas belajar siswa selama pembelajaran berlangsung. 
11. Pada pelaksanaan tindakan siklus II, lebih memantapkan materi dan meminimalkan siswa agar tidak ada waktu untuk bermain bersama temannya.

\section{Observasi/Analisis data siklus II Pertemuan 4}

Sama halnya pada siklus I, observasi atau pengamatan siklus II ini dilakukan oleh guru teman sejawat di SDN No. 343 Kubangan Tompek mulai dari awal pelaksanaan tindakan sampai akhir pelaksanaan tindakan pembelajaran yang menerapkan model pembelajaran kerja lapangan sebagai upaya meningkatkan aktivitas belajar siswa pada materi Tumbuhan hijau pada pelajaran Ilmu Pengetahuan Alam. Dari hasil observasi ini dapat dilihat bahwa kegiatan pembelajaran pada siklus II ini telah berlangsung dengan sangat baik.

Setelah proses observasi selam pembelajaran dilakukan, selanjutnya dilakukan kembali analisis dari data aktivitas belajar yang ditetapkan. Dari aktivitas belajar siklus II yang didapat kemudian kembali reduksi dan dipaparkan bentuk tabel dengan menggunakan rumus yang sama seperti siklus I. Ternyata 21 orang siswa $(87,5 \%)$ yang sudah memiliki ketuntasan belajar, sedangkan selebihnya yaitu 3 orang siswa $(12,5 \%)$ belum memiliki ketuntasan belajar. Nilai rata - rata yang diperoleh hanya mencapai 78,77 .
Tabel Aktivitas Belajar Siswa Pada Siklus II pertemuan 4

\begin{tabular}{|c|c|c|c|}
\hline \multirow{2}{*}{$\begin{array}{c}\text { No } \\
\text { Responden }\end{array}$} & \multicolumn{3}{|c|}{ Skor } \\
\hline & Jlh & $\%$ & Kriteria \\
\hline 1 & 74 & 77.08 & Aktif \\
\hline 2 & 72 & 75.00 & Aktif \\
\hline 3 & 74 & 77.08 & Aktif \\
\hline 4 & 76 & 79.17 & Aktif \\
\hline 5 & 85 & 88.54 & Aktif \\
\hline 6 & 69 & 71.88 & Aktif \\
\hline 7 & 76 & 79.17 & Aktif \\
\hline 8 & 70 & 72.92 & Aktif \\
\hline 9 & 75 & 78.13 & Aktif \\
\hline 10 & 71 & 73.96 & Aktif \\
\hline 11 & 72 & 75.00 & Aktif \\
\hline 12 & 71 & 73.96 & Aktif \\
\hline 13 & 64 & 66.67 & Aktif \\
\hline 14 & 70 & 72.92 & Aktif \\
\hline 15 & 72 & 75.00 & Aktif \\
\hline 16 & 69 & 71.88 & Aktif \\
\hline 17 & 70 & 72.92 & Aktif \\
\hline 18 & 68 & 70.83 & Aktif \\
\hline 19 & 71 & 73.96 & Aktif \\
\hline 20 & 51 & 53.13 & $\begin{array}{l}\text { Tidak } \\
\text { Aktif }\end{array}$ \\
\hline 21 & 50 & 52.08 & $\begin{array}{l}\text { Tidak } \\
\text { Aktif }\end{array}$ \\
\hline 22 & 66 & 68.75 & Aktif \\
\hline 23 & 70 & 72.92 & Aktif \\
\hline 24 & 69 & 71.88 & Aktif \\
\hline 25 & 70 & 72.92 & Aktif \\
\hline 26 & 63 & 65.63 & Aktif \\
\hline Jlh & & & \\
\hline
\end{tabular}

Dari data yang didapat terlihat bahwa aktivitas belajar siswa pada pertemuan 4 siklus II materi Tumbuhan hijau pada pelajaran Ilmu Pengetahuan Alam terus mengalami perbaikan. Dari 26 orang siswa yang 
menjadi subjek dalam penelitian ini, ternyata pada siklus II pertemuan 4 menunjukan bahwa 24 orang siswa yang sudah aktif dalam belajar $(92,31 \%)$, dan sisanya 2 orang siswa tidak aktif dalam belajar (7,69\%).

Tabel Deskripsi Aktivitas Belajar Siklus II Pertemuan 4

\begin{tabular}{|c|c|c|c|c|}
\hline No & Hasil Tes & $\begin{array}{c}\text { Jumlah } \\
\text { Siswa }\end{array}$ & $\begin{array}{c}\text { Persentase } \\
(\%)\end{array}$ & Keterangan \\
\hline 1 & Skor $\leq 65$ & 2 & 7.69 & $\begin{array}{c}\text { Tidak } \\
\text { Aktif }\end{array}$ \\
\hline 2 & Skor $>65$ & 24 & 92.31 & Aktif \\
\hline
\end{tabular}

Data deskripsi aktivitas belajar siswa siklus II pertemuan 4 tabel diatas dapat juga dilihat seperti pada gambar histogram berikut.

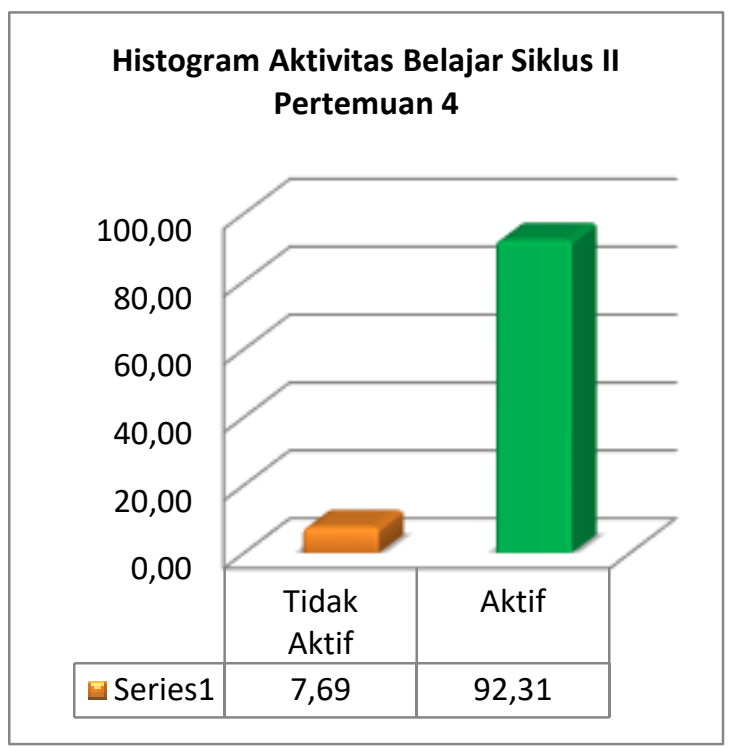

Gambar Histogram Aktivitas Belajar Siklus II Pertemuan 4
Tabel Perbandingan Aktivitas belajar Siklus I dan Siklus II

\begin{tabular}{|c|c|c|}
\hline Pembelajaran & $\begin{array}{c}\text { Persentase } \\
(\%) \text { siswa } \\
\text { aktif }\end{array}$ & $\begin{array}{c}\text { Persentase } \\
(\%) \text { Siswa } \\
\text { Tidak aktif }\end{array}$ \\
\hline Siklus I Pertemuan 1 & 19.23 & 80.77 \\
\hline Siklus I Pertemuan 2 & 42.31 & 57.69 \\
\hline Siklus II Pertemuan 3 & 69.23 & 30.77 \\
\hline Siklus II Pertemuan 4 & 92.31 & 7.69 \\
\hline
\end{tabular}

Histogram peningkatan aktivitas belajar siswa

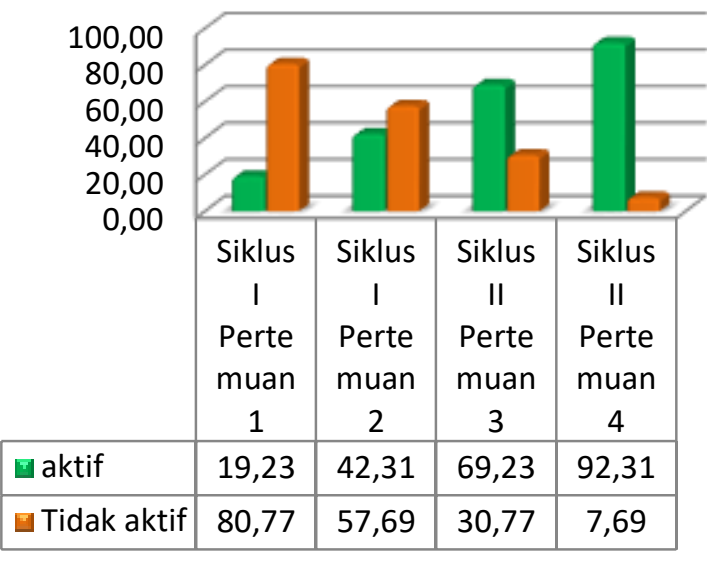

Gambar Grafik Perbandingan

Siklus I dan Siklus II

\section{Refleksi siklus II Pertemuan 4}

Dari tes hasil analisis yang dilakukan disimpulkan bahwa telah terjadi peningkatan keaktifan belajar siswa. Peningkatan ini terjadi setelah diberikan pembelajaran dengan menggunakan model pembelajaran kerja lapangan yang dirancang pada siklus II yang beracuan pada pengalaman disiklus I. 


\section{Hasil Penelitian}

Berdasarkan deskripsi data penelitian, maka pada penelitian ini didapatkan hasil sebagai berikut :

Setelah pemberian tindakan pada siklus I sebanyak dua kali pertemuan, siswa diberikan tes aktivitas belajar siswa yang kemudian diperoleh pada siklus I pertemuan 1 dari 26 orang siswa yang menjadi subjek dalam penelitian ini, ternyata hanya 5 orang siswa (1923\%) yang sudah aktif dalam belajar, sedangkan selebihnya yaitu 21 orang siswa $(80,77 \%)$ belum aktif didalam belajar. Nilai rata - rata yang diperoleh hanya mencapai 56,09. Kemudian data siklus I pertemuan kedua, dari 26 orang siswa ternyata 11 orang siswa yang aktif di dalam belajar $(42,31 \%)$, dan terdapat 15 orang siswa yang belum aktif dalam belajar $(57,69 \%)$. Dan nilai rata-rata pada siklus I pertemuan 2 adalah 63,22 . Beberapa faktor yang membuat siswa belum bisa mencapai keaktifan belajar yang diharapkan diantaranya kurang pahamnya siswa dengan proses melakukan cara mengerjakan soal pada materi Tumbuhan hijau pada pelajaran Ilmu Pengetahuan Alam.

Kemudian setelah diberikan tindakan pada siklus II sebanyak dua kali pertemuan, siswa kembali diberi test aktivitas belajar pada siklus II pertemuan 3 yang kemudian diperoleh ternyata dari 26 orang siswa, diperoleh 18 orang yang sudah aktif $(69,23 \%)$ dan 8 orang yang belum aktif dalam belajar $(530,77 \%)$. Dan nilai rata-rata siklus II pertemuan 3 adalah 71,03. Kemudian, di siklus II pertemuan 4, terdapat 24 orang siswa yang aktif dalam belajar $(92,31 \%)$ dan 2 orang yang belum aktif dalam belajar (7,69\%). Nilai rata-rata siklus II pertemuan 4 adalah 87,86. Beberapa orang belum tuntas dalam pembelajaran dikarenakan siswa yang belum aktif tersebut dalam keadaan kurang sehat secara fisik dan siswa tersebut tidak fokus mengikuti pembelajaran, dan kemudian siswa tidak mengulang pembelajaran dengan baik. Peningkatan persentase nilai ratarata aktivitas belajar siswa dari tes sebelumnya yaitu mencapai $31,77 \%$ di siklus II. Sehingga dapat disimpulkan penelitian ini mampu meningkatkan aktivitas belajar siswa pada mata pelajaran Sains.

\section{Pembahasan Hasil Penelitian}

Dari analisis data yang telah dilakukan dapat disimpulkan bahwasannya dengan menggunakan model pembelajaran kerja lapangan dapat memberikan pengaruh serta meningkatkan aktivitas belajar mengenai Tumbuhan hijau pada pelajaran Ilmu Pengetahuan Alam.

Setelah pemberian tindakan pada siklus I sebanyak dua kali pertemuan, siswa diberikan tes aktivitas belajar yang kemudian diperoleh pada siklus I pertemuan 1 dari 26 orang siswa yang menjadi subjek dalam penelitian ini, ternyata 
hanya 5 orang siswa $(19,23 \%)$ yang sudah aktif dalam belajar, sedangkan selebihnya yaitu 21 orang siswa $(80,77 \%)$ belum aktif didalam belajar. Nilai rata - rata yang diperoleh hanya mencapai 56,09. Kemudian di siklus I pertemuan kedua, dari 26 orang siswa ternyata 11 orang siswa yang aktif di dalam belajar $(42,31)$, dan terdapat 15 orang siswa yang belum aktif dalam belajar $(57,69 \%)$. Nilai rata-rata pada siklus I pertemuan 2 adalah 63,22.

Hasil klasikal belum mencapai $85 \%$, dikarenakan ada beberapa faktor siswa tersebut belum bisa mencapai tingkat ketuntasan belajar yaitu kurang pahamnya siswa dengan materi Tumbuhan hijau pada pelajaran Ilmu Pengetahuan Alam dengan baik dan siswa kurang mengulang pembelajaran yang telah diberikan, serta kurang aktifnya siswa dalam kegiatan pembelajaran. Untuk selanjutnya perlu diadakannya perbaikan tindakan pada siklus II.

Pada siklus I guru menemukan banyak kesulitan yang dialami siswa dalam pembelajaran diantaranya :

1. Masih banyak siswa yang masih belum paham mengenai Ilmu Pengetahuan Alam pada materi Tumbuhan hijau.

2. Pada saat melaksanaan pembelajaran di lapangan, cenderung siswa tidak serius dan mengalihkan tugas yang diberikan dengan bermain bersama temannya.
3. Dalam pelaksanaan diskusi, masih banyak siswa yang bercerita dengan teman bukan berdiskusi.

4. Dalam menemukan masalah, siswa juga masih butuh bimbingan guru.

5. Motivasi siswa cukup rendah pada siklus I ini.

6. Siswa kurang mengulang pembelajarannya di rumah.

Kemudian, ada pun beberapa keberhasilan siklus I adalah sebagai berikut :

1. Siswa lebih mandiri dalam menghadapi masalah belajarnya.

2. Siswa sudah mampu menganalisis permasalahan yang diberikan.

3. Siswa memiliki motivasi belajar yang cukup meningkat.

4. Pembelajaran aktivitas luar kelas mulai memotivasi siswa.

5. Hasil belajar mulai meningkat.

6. Siswa sudah mampu membedakan mana jenis akar, daun-daun.

Kemudian pada pembelajaran disiklus II dapat dilihat bahwa telah terjadi peningkatan aktivitas belajar siswa dari siklus sebelumnya. Dari tes hasil analisis yang dilakukan disimpulkan bahwa telah terjadi peningkatan kemampuan siswa. Peningkatan ini terjadi setelah diberikan pembelajaran dengan menggunakan model pembelajaran kerja lapangan yang lebih baik lagi 
yang dirancang pada siklus II yang beracuan pada refleksi dan pengalaman di siklus I. Kemudian setelah diberikan tindakan pada siklus II sebanyak dua kali pertemuan, siswa kembali diberi test aktivitas belajar pada siklus II pertemuan tiga yang kemudian diperoleh ternyata dari 26 orang siswa, diperoleh 18 orang yang sudah aktif $(69,23 \%)$ dan 8 orang yang belum aktif dalam belajar $(30,77 \%)$. Dan nilai ratarata siklus II pertemuan 3 adalah 71,03. Kemudian, di siklus II pertemuan 4 , terdapat 24 orang siswa yang aktif dalam belajar $(92,31 \%)$ dan 2 orang yang belum aktif dalam belajar (7,69\%). Nilai rata-rata siklus II pertemuan 4 adalah 87,86.

Ini berarti terlihat ada peningkatan dari siklus ke siklus. Peningkatan persentase nilai rata-rata aktivitas belajar siswa dari tes sebelumnya yaitu 56,09 menjadi 87,86 dan peningkatan rata-rata aktivitas belajar siswa sebesar 31,77\% dan pada siklus II didapat hasil bahwa kriteria ketuntasan belajar secara klasikal yang diharapkan telah tercapai.

Ada beberapa keberhasilan
yang diperoleh pada pelaksanaan siklus II :

1. Aktivitas belajar siswa lebih meningkat.

2. Motivasi siswa juga semakin meningkat.

3. Pembelajaran di luar kelas dilaksanakan seefektif mungkin oleh siswa.
4. Siswa mampu menganalisis permasalahan.

5. Siswa berdiskusi dengan baik.

6. Siswa berhasil menganalisis permasalahan.

Namun masih ada beberapa siswa yang belum memperoleh ketuntasan belajar per individu walaupun nilai yang diperoleh sudah meningkat dibandingkan pada siklus I. Untuk memperbaiki masalah siswa tersebut dilakukan pengayaan dan belajar tambahan untuk meningkatkan aktivitas belajar siswa tersebut.

Pada proses pembelajaran, banyak mendapatkan evaluasi dalam meningkatkan aktivitas belajar yang maksimal. Diperlukan kreatifitas guru dalam mengembangkan pembelajaran yang dilaksanakannya. Berbagai cara agar pembelajaran meningkat, salah satunya penyampaian materi dengan menggunakan model pembelajaran. Model pembelajaran sangat dibutuhkan karena semakin model yang digunakan menarik maka semakin siswa senang mengikuti pembelajaran, guru sebaiknya meninggalkan model pembelajaran konvensional yang monoton. Pada penelitian ini, model pembelajaran kerja lapangan cukup berhasil karena dilihat pada peningkatan yang terjadi pada siklus II. 
KESIMPULAN

Berdasarkan analisis dan pembahasan pada penelitian maka dapat ditarik kesimpulan bahwa : Pembelajaran Dengan Menerapkan Model Pembelajaran Kerja Lapangan Dapat Meningkatkan Aktivitas Belajar IPA Siswa Kelas V-A SDN No. 343 Kubangan Tompek T.P 2014/2015.

Sebagai saran yang dapat diberikan peneliti adalah sebagai berikut:

1. Disarankan kepada seluruh guru kelas untuk mempertimbangkan penggunaan model pembelajaran harus disesuaikan dengan materi karena hal ini dapat membangkitkan semangat belajar siswa dan hasil belajar siswa.

2. Dari hasil penelitian ditemukan kebanyakan siswa tidak berani mengajukan pendapat ataupun pertanyaan tentang hal-hal yang belum dimengerti secara langsung kepada guru, dan tidak melakukan gerakan yang efektif ketika proses pembelajaran berlangsung, maka disarankan kepada guru yang akan melaksanakan pembelajaran dapat mempelajari bagaimana cara memotivasi siswa untuk berani berbicara maupun bertanya.

3. Kepada seluruh elemen pendidikan untuk dapat mencoba melakukan model Penelitian Tindakan Kelas (PTK) dengan menggunakan model pembelajaran kerja lapangan.
4. Model pembelajaran kerja lapangan cukup efektif dalam pembelajaran seperti pembelajaran Ilmu Pengetahuan Alam, sehingga perlu kiranya mempertimbangkan setiap pembelajaran IPA dengan model ini.

\section{DAFTAR RUJUKAN}

Abdul Sani, Ridwan. 2013. Inovasi Pembelajaran. Jakarta: Bumi Aksara.

Dewi, Rosmala. 2010. Penelitian Tindakan Kelas. Medan: Pascasarjana Unimed.

Hamdani. 2011. Strategi Belajar Mengajar. Bandung: Pustaka Setia.

Istarani. 2011. 58 Model Pembelajaran Inovatif. Medan: Media Persada.

Istarani. 2012. Kumpulan 39 Metode Pembelajaran. Medan: Iscom Medan.

Maman, Rumanta. 2013. Pratikum IPA di SD. Banten: Universitas Terbuka.

Mohammad, Jauhari. 2013. Implementasi PAIKEM dari Behavioristik sampai Konstruktivistik. Jakarta: Prestasi Pustaka.

Oemar, Hamalik. 2010. Proses Belajar Mengajar. Bandung: Bumi Aksara.

Sardiman. 2011. Interaksi Belajar Mengajar. Jakarta: Raja Grafindo.

Slameto. 2010. Belajar Dan Faktor Faktor Yang Mempengaruhi. Jakarta: Rineka Cipta. 
Suharsimi, Arikunto. (2010). Penelitian Tindakan Kelas. Jakarta: Rineka Cipta.

Wina, Sanjaya. 2011. Strategi Pembelajaran Berorientasi Standard Proses Pendidikan. Bandung: Kencana Prenada Media.

Trianto. (2011). Mendesain Model Pembelajaran Inovatif Progresif. Jakarta: Kencana Perdana Media Group 